\title{
Isotopic assessment of prey and habitat preferences of a cetacean community in the southwestern South Atlantic Ocean
}

\author{
Luciana Riccialdelli ${ }^{1,2, *}$, Seth D. Newsome ${ }^{3}$, Marilyn L. Fogel ${ }^{4}$, R. Natalie P. Goodall ${ }^{1,2}$ \\ ${ }^{1}$ Centro Austral de Investigaciones Científicas (CADIC), Bernardo A. Houssay 200, and \\ ${ }^{2}$ Museo Acatushún de Aves y Mamíferos Marinos Australes, Sarmiento 44; Ushuaia (9410), Tierra del Fuego, Argentina \\ ${ }^{3}$ Department of Zoology and Physiology, University of Wyoming, 1000 E. University Avenue, Dept. 3166, Laramie, \\ Wyoming 82071, USA
}

${ }^{4}$ Geophysical Laboratory, Carnegie Institution of Washington, 5251 Broad Branch Road NW, Washington, DC 20015-1305, USA

\begin{abstract}
We used stable carbon $\left(\delta^{13} \mathrm{C}\right)$ and nitrogen $\left(\delta^{15} \mathrm{~N}\right)$ isotope analysis to investigate the trophic ecology of 8 small cetacean species of the southwestern South Atlantic Ocean: 6 delphinids (Grampus griseus, Lagenorhynchus cruciger, L. australis, Lissodelphis peronii, Pseudorca crassidens, and Cephalorhynchus commersonii) and 2 phocoenids (Phocoena dioptrica and P. spinipinnis). We also analyzed samples of possible prey collected from oceanic and coastal habitats adjacent to Tierra del Fuego. Cetacean bone-collagen $\delta^{13} \mathrm{C}$ and $\delta^{15} \mathrm{~N}$ data revealed information on both habitat and prey preferences. We observed an isotopic continuum in which coastal species had the highest values of $\delta^{13} \mathrm{C}$ and $\delta^{15} \mathrm{~N}$ (L. australis), while oceanic and southern species had the lowest values $(L$. cruciger and $P$. dioptrica), indicative of offshore foraging in cold oceanic waters near the Antarctic Convergence. Overlap in mean isotope values between $C$. commersonii and $P$. spinipinnis suggests that these species may have similar habitat and/or prey preferences. Isotope results for L. peronii, P. crassidens, and $G$. griseus suggest that at these latitudes $\left(\sim 54^{\circ} \mathrm{S}\right)$ they forage on the outer continental shelf. G. griseus show bimodal isotopic patterns, suggesting that 2 ecotypes that forage in different habitats and/or consume different prey items occur in this region of the southwestern Atlantic Ocean. The isotopic data presented here provide insight into the ecology of these cetaceans, with relevant implications for their successful management and conservation.
\end{abstract}

KEY WORDS: Stable isotopes $\cdot \delta^{13} \mathrm{C} \cdot \delta^{15} \mathrm{~N} \cdot$ Small cetaceans $\cdot$ Foraging areas $\cdot$ Food/prey $\cdot$ South Atlantic Ocean · Southern Ocean

\section{INTRODUCTION}

Management decisions ideally should be guided by accurate ecological information regarding the structure and function of ecosystems. For open-ocean marine ecosystems, this includes an understanding of the role of elusive and highly mobile top predators, which are difficult to study in their natural habitats. Information on prey preferences of top marine predators is also important for understanding the potential of direct (e.g. bycatch mor- tality) and/or indirect (e.g. exploitation competition) interactions with fisheries (Reeves et al. 2003). Despite the need for this type of ecological information for successful conservation and management programs, cetaceans have not been intensively studied in the southwestern Atlantic Ocean. This is in part because it is difficult to collect this type of ecological data for small cetaceans, especially species that occur offshore of Tierra del Fuego, given its extreme meteorological conditions and extensive coastline with limited access. 
At present, foraging data for small cetaceans of the southwestern South Atlantic is based mainly on the analysis of stomach contents from stranded or incidentally captured animals (Goodall \& Galeazzi 1985, Goodall \& Schiavini 1995). These studies provide crucial data on general foraging preferences, but they produce only a snapshot of prey preferences and the trophic niche of each species. While some studies based on data from several animals provide somewhat complete information (Bastida et al. 1988, Schiavini et al. 1997, Koen Alonso et al. 1999), other studies are based on data from only a few individuals that stranded far from their normal distribution (Fernández et al. 2003), which may not represent an accurate characterization of the foraging habits of the species. Few studies were conducted by direct observation of live animals from ship or shore (Viddi \& Lescrauwaet 2005).

Furthermore, there are numerous difficulties in describing marine mammal diet via stomach content or scat analysis (Pierce et al. 2004, Sheppard \& Harwood 2005). Specifically, variation in digestion rates and the identifiability of prey remains can create biased estimates of diet composition (Sheffield et al. 2001, Staniland 2002, Sheffield \& Grebmeier 2009). Moreover, gut contents can vary considerably among individuals since it is a reflection of what the animal ate recently (within 24 to $72 \mathrm{~h}$ ). The analysis of stomach contents of stranded animals can create an additional problem because such samples likely include sick individuals in poor nutritional status that may not have fed in the days prior to death (Pierce et al. 2004).

Stable-isotope analyses are complementary with traditional methods of diet analysis in marine mammals, allowing for an independent measure of prey and habitat preferences (Best \& Schell 1996, Aurioles et al. 2006, Newsome et al. 2010). Stable-isotope analysis offers some advantages over traditional methods of diet analysis by providing a time-integrated assessment of ecological information (Michener \& Kaufman 2007). This approach is based on a predictable relationship between the stable-isotope composition of a consumer and its food, often referred to as trophic discrimination. In general, carbon $\left(\delta^{13} \mathrm{C}\right)$ and nitrogen $\left(\delta^{15} \mathrm{~N}\right)$ isotope values increase by $\sim 1$ to $2 \%$ and $\sim 3$ to $5 \%$ respectively with each increase in trophic level in a food web (DeNiro \& Epstein 1978, 1981, Schoeninger $\&$ DeNiro 1984). Since different tissues have different isotopic turnover rates, trophic information can be evaluated over different temporal scales via analysis of multiple tissue types, such as skin, muscle, bone, teeth, hair, blood, or liver, that are collected from live or dead animals, and even fossils (Koch 2007).

Isotope values of primary producers in the ocean also vary spatially and temporally as a function of physical and oceanographic conditions. Previous work in north- ern and central Patagonian waters and the southern South Atlantic near Antarctica show significant variations in both $\delta^{13} \mathrm{C}$ and $\delta^{15} \mathrm{~N}$ values among food webs (Forero et al. 2004, Lewis et al. 2006, Ciancio et al. 2008, Drago et al. 2009), which mirror the patterns reported by Rau et al. (1982) and Goericke \& Fry (1994). A negative latitudinal decline has been documented in $\delta^{13} \mathrm{C}$ values for marine phytoplankton, which creates large-scale gradients in carbon isotope values at the base of the food web along the Atlantic and Pacific Oceans from temperate waters toward the Antarctic and Arctic zones (Rau et al. 1982, Goericke \& Fry 1994). The $\delta^{13} \mathrm{C}$ value of phytoplankton also changes along a coastal-to-offshore gradient, with nearshore waters characterized by higher $\delta^{13} \mathrm{C}$ values than offshore habitats (Michener \& Kaufman 2007). Spatial patterns in $\delta^{15} \mathrm{~N}$ values among marine ecosystems are more complex, but latitudinal and longitudinal variations have been reported in the North Pacific Ocean and the Bering, Beaufort, and Chukchi seas (Schell et al. 1998, Burton \& Koch 1999, Michener \& Kaufman 2007). In general, variation in $\delta^{13} \mathrm{C}$ and $\delta^{15} \mathrm{~N}$ values at the base of the food web is imprinted on the entire food chain, and has been used extensively in marine mammal ecology to assess movement patterns and habitat use (Schell et al. 1989, Best \& Schell 1996, Burton \& Koch 1999, Newsome et al. 2010).

Comparison of $\delta^{15} \mathrm{~N}$ values among individuals or species are primarily used to evaluate trophic level, while $\delta^{13} \mathrm{C}$ values are useful indicators of habitat use (Post 2002, Hobson et al. 2004, Newsome et al. 2007). Stable-isotope analysis is an increasingly common tool in the study of marine-mammal ecology (Newsome et al. 2010), especially in regards to modeling marine trophic networks and the role that top marine consumers have in the structure and function of marine ecosystems (Pauly et al. 1998, Porras Peters et al. 2008).

In the present study, we analyzed bone samples from cetaceans that stranded or were incidentally captured on Tierra del Fuego beaches over the past 3 decades. Because bone collagen turnover rates are slow and represent ecological information integrated over 5 to 10 yr depending on ontogenetic stage, bone collagen represents a long-term integrator of dietary inputs (Koch 2007), and its superior preservation qualities in comparison to soft tissues (e.g. muscle or skin) allows for a post-mortem assessment of the ecological characteristics at the individual level. Sporadic fluctuations in isotope values due to periodic stress, disease or nutritional stress, or recent shift in foraging behavior or movement patterns (Hedges et al. 2005) are likely not reflected in the isotopic composition of collagen as in other tissues (e.g. blood, skin, liver, or muscle) with shorter turnover rates. To complement the study, we also analyzed potential prey items. 
Our principal goals in the present study were to: (1) investigate the prey and habitat preferences of 8 small cetacean species from the southwestern South Atlantic, and (2) evaluate whether these cetaceans tracked latitudinal and longitudinal baseline gradients in stable isotope values. Based on a priori knowledge of each species, we predicted that: (a) cetacean species would have significant isotopic differences, because they have different foraging areas and they occupy different trophic levels; (b) generalist species known to consume a wide range of prey types and/or forage in different habitats (e.g. coastal, continental shelf-slope break) would exhibit greater variation in isotopic values in comparison to specialists with relatively narrow prey and/or habitat preferences; and (c) species that forage near the coast and/or in northern areas would have more enriched $\delta^{13} \mathrm{C}$ and $\delta^{15} \mathrm{~N}$ values, while species typically associated with oceanic and/or southern areas would have more depleted isotope values, which generally track the spatial gradients in stable isotope values of primary producers in the southern South Atlantic and Southern Ocean. Our analysis of these cetaceans and their common prey provides novel ecological information important for understanding the structure of marine ecosystems in this region, and has important implications for their successful management and conservation.

\section{MATERIALS AND METHODS}

Species descriptions. Burmeister's porpoise: Phocoena spinipinnis is an endemic species to the nearshore waters from southern Brazil $\left(28^{\circ} 48^{\prime} \mathrm{S}\right)$ to Cape Horn $\left(56^{\circ} \mathrm{S}\right)$, and up the west coast of South America to Peru ( $\left.5^{\circ} \mathrm{S}\right)$ (Goodall et al. 1995). There are few detailed studies about the diet of this species along its distribution. The only food records are from Uruguay (Brownell \& Praderi 1984), Peru (Reyes \& Van Waerebeek 1995), Chile (Escare \& Oporto 1992), and from 5 specimens from Tierra del Fuego, Argentina (Goodall et al. 1995); these showed remains of fish, mysid shrimp, and euphausiids.

Spectacled porpoise: Phocoena dioptrica has a circumpolar distribution in southern oceans and, unlike most phocoenids, but similar to Phocoenoides dalli, seems to inhabit both coastal and oceanic waters (Fajardo-Mellor et al. 2006). Little is known about the biology, distribution, abundance, and trophic behavior of this species, as there is only 1 record of prey remains from a 6 yr old male that stranded in Chubut, Argentina (Goodall \& Schiavini 1995).

Commerson's dolphin: Cephalorhynchus commersonii is one of the most common dolphins in the area. It is considered a coastal species that ranges along the coast of Patagonia from Río Negro $\left(40^{\circ} 30^{\prime} \mathrm{S}\right)$ to the Strait of Magellan, Cape Horn, and the Falkland/ Malvinas Islands (Best 2007). Based on geographic, morphological, and genetic data, it was determined that a separate subspecies exists at Kerguelen Island (Robineau et al. 2007). There are several studies on trophic habits along the range of the South American subspecies (Bastida et al. 1988, Clarke \& Goodall 1994, Berón Vera et al. 2001). These studies showed that C. commersonii is an opportunistic coastal feeder over the shallow waters of the continental shelf, feeding on several types of fish, squid, and crustaceans (Bastida et al. 1988).

Peale's dolphin: Lagenorhynchus australis inhabits coastal waters along southern South America, from northern Patagonia to Cape Horn, including the Falklands/Malvinas Islands, and goes as far north as $33^{\circ} \mathrm{S}$ in Chile (Goodall et al. 1997a). L. australis is particularly common around Tierra del Fuego. At the south end of its distribution, L. australis has been observed frequenting protected channels and fjords that have kelp beds of the species Macrocystis pyrifera (Goodall et al. 1997a, Viddi \& Lescrauwaet 2005), where it forages on demersal and bottom species. In the northern part of its range, it seems to be more pelagic and inhabits open coast over the continental shelf (Schiavini et al. 1997).

False killer whale: Pseudorca crassidens is widely distributed and is commonly found offshore in tropical and temperate waters (Stacey et al. 1994). Stomach contents have been studied from Brazil, South Africa, and the Strait of Magellan (Ross 1979, Pinedo \& Rosas 1989, Koen Alonso et al. 1999, Sekiguchi et al. 1992). Koen Alonso et al. (1999) suggested that P. crassidens in the southwestern South Atlantic are opportunistic feeders on pelagic, schooling, and locally abundant squid and fish.

Southern right whale dolphin: Lissodelphis peronii is a circumpolar species that inhabits the subantarctic regions between 35 and $65^{\circ} \mathrm{S}$, north and south of the boundaries of the Subtropical and Antarctic convergences (Newcomer et al. 1996). Food records from New Zealand, Chile, and the South Shetland Islands included fish and squid (Torres \& Aguayo 1979, Baker 1981, Van Waerebeek \& Oporto 1990).

Risso's dolphin: Grampus griseus is found worldwide in temperate and tropical offshore oceanic waters (Baumgartner 1997, Olavarría et al. 2001) but only recently in the subantarctic (Goodall \& Schiavini 1992). This species is considered a deep sea squid consumer. Baker (1974) and Ross (1979) in New Zealand and Sekiguchi et al. (1992) in South Africa reported G. griseus stomach contents to have squid and fish. In Tierra del Fuego, only 4 individuals examined had 
prey items in their stomachs, which were otoliths and squid beaks (R. N. P. Goodall unpubl. data).

Hourglass dolphin: Lagenorhynchus cruciger is considered an oceanic species found in cold waters of the Antarctic and subantarctic, with a circumpolar distribution (Goodall et al. 1997b). Little is known about its basic biology and its trophic ecology due to its oceanic behavior and few records of stranded animals (Fernández et al. 2003).

Sample collection. All cetacean specimens were collected along the northeast and south coasts of Tierra del Fuego, Argentina (52 to $54^{\circ} \mathrm{S}$ and 68 to $69^{\circ} \mathrm{W}$ ) (Fig. 1). Specimens were collected as part of an ongoing long-term study (1975 to present) and represent both single and mass stranding events, as well as incidental captures in artisanal shore-set fixed gillnets (Goodall 1978, Goodall et al. 1994).

The cetacean specimens were sampled from cleaned skeletons held at the Museo Acatushún de Aves y Mamíferos Marinos Australes, Tierra del Fuego, Argentina. Small bone fragments $(n=371)$ were sampled from the pterygoid region of the skull or from chevron bones of 6 different delphinid and 2 phocoenid species (see Table 1). Five of these species, Grampus griseus $(\mathrm{n}=48)$, Lagenorhynchus cruciger $(\mathrm{n}=5)$, Lissodelphis peronii ( $\mathrm{n}=37$ ), Phocoena dioptrica $(\mathrm{n}=87$ ), and Pseudorca crassidens ( $\mathrm{n}=27$ ), are considered to inhabit mainly offshore waters. The 3 others, Cephalorhynchus commersonii ( $\mathrm{n}=121)$, Lagenorhynchus australis $(\mathrm{n}=39)$, and Phocoena spinipinnis $(\mathrm{n}=7)$, are considered to be nearshore/coastal species.

We also analyzed samples of possible prey collected from oceanic and coastal areas of Tierra del Fuego. The prey specimens were obtained from commercial fishing vessels operating with bottom trawlers, artisanal shore-set fixed gillnet along the northeast and south coasts of Tierra del Fuego, and a few items from the stomachs of incidentally caught cetaceans (Cephalorhynchus commersonii). The sampling area was located between 51 and $54^{\circ} \mathrm{S}$ and 62 and $68^{\circ} \mathrm{W}$, covering coastal $\left(54^{\circ} 17^{\prime} \mathrm{S} 66^{\circ} 41^{\prime} \mathrm{W}, 54^{\circ} 52^{\prime} \mathrm{S} 67^{\circ} 16^{\prime} \mathrm{W}\right.$, $\left.53^{\circ} 57^{\prime} \mathrm{S} 67^{\circ} 27^{\prime} \mathrm{W}\right)$ and pelagic habitats $\left(53^{\circ} 09^{\prime} \mathrm{S}\right.$

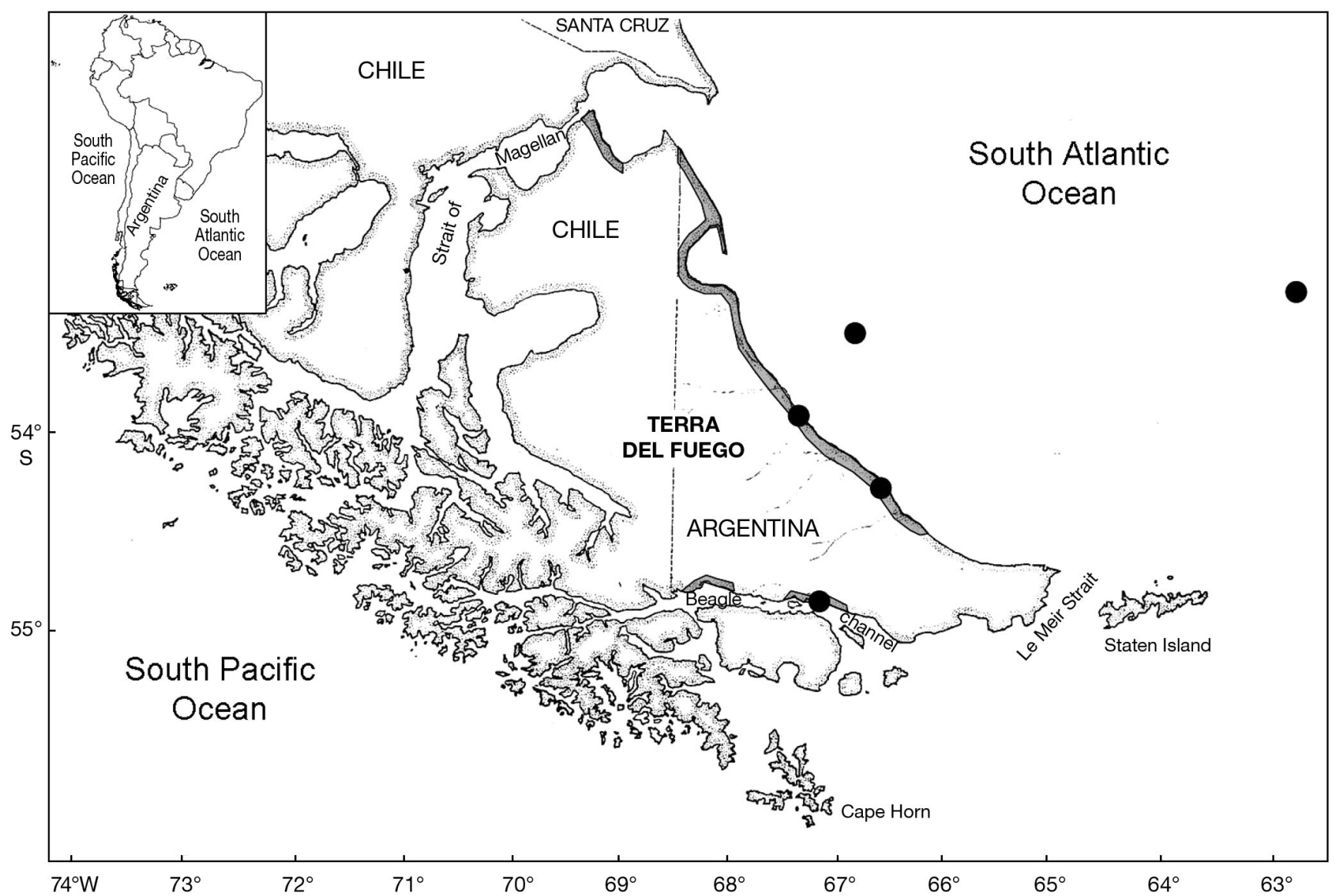

Fig. 1. Study area, subantarctic waters of the South Atlantic Ocean around Tierra del Fuego, Argentina (inset: South America). Prey sampling points ( ) and stranding sites (gray area) are shown. Most strandings occurred on the northeastern coast of Tierra del Fuego 
$\left.62^{\circ} 48^{\prime} \mathrm{W}, 53^{\circ} 57^{\prime} \mathrm{S} 67^{\circ} 27^{\prime} \mathrm{W}\right)$ over the southern Patagonian area (Fig. 1). Twenty-nine species of possible prey were studied, for a total of 194 individual specimens. We compared our prey results with isotope values of similar prey types collected in the southwestern South Atlantic (Ciancio et al. 2008). We grouped the prey into 7 categories corresponding to general taxonomy and ecological characteristics (see Table 2): coastal and benthic fish (e.g. zoarcids, Patagonotothen spp.), benthopelagic fish (e.g. Merluccius hubbsi, Merluccius australis, Salilota australis), pelagic fish (e.g. Odonthestes spp., Sprattus fuegensis), squid (e.g. Illex argentinus, Loligo gahi), octopus (e.g. Enteroctopus megalocyathus), crustaceans (e.g. Munida spp., Halicarcinus spp.), and zooplankton (e.g. euphausiids and copepods).

$\boldsymbol{\delta}^{\mathbf{1 3}} \mathbf{C}$ and $\boldsymbol{\delta}^{\mathbf{1 5}} \mathbf{N}$ analysis. Collagen was extracted from each cetacean bone sample by demineralization in $0.2 \mathrm{~N} \mathrm{HCl}$ for $\sim 72$ to $96 \mathrm{~h}$ at room temperature with frequent replacement of fresh $\mathrm{HCl}$ solution during this period. Samples were then rinsed in distilled water to achieve a more neutral $\mathrm{pH}$. Lipids were removed by repeated rinsing with a 2:1 chloroform:methanol solution. The resulting collagen preparations were then rinsed several times with distilled water and dried in an oven at $60^{\circ} \mathrm{C}$ for $\sim 24 \mathrm{~h}$.

Bone and muscle were sampled from each prey specimen and stored at $-18^{\circ} \mathrm{C}$ until preparation. In general, prey bone samples and cephalopod beaks from stomach contents had been previously preserved in $70 \%$ alcohol; samples were rinsed several times in distilled water until $\mathrm{pH}$ was neutral before treatment for isotopic analysis. Prey bone samples were demineralized and lipid-extracted using the same approach for cetacean samples described in the previous paragraph. Muscle samples were oven dried at $60^{\circ} \mathrm{C}$ for $48 \mathrm{~h}$ and lipids were extracted in the manner described in the previous paragraph.

Dried samples ( 0.5 to $0.6 \mathrm{mg}$ ) were weighed into tin capsules $(3 \times 5 \mathrm{~mm})$ and analyzed with a Carlo Erba Elemental Analyzer interfaced with a DELTA ${ }^{\text {plus }}$ XLThermo Finnigan isotope-ratio mass spectrometer at the Geophysical Laboratory, Carnegie Institution of Washington, Washington, DC. Results are expressed in delta $(\delta)$ notation using the equation:

$$
\delta^{13} \mathrm{C} \text { or } \delta^{15} \mathrm{~N}=\left[\left(\mathrm{R}_{\text {sample }} / \mathrm{R}_{\text {standard }}\right)-1\right] \times 1000
$$

where $\mathrm{R}_{\text {sample }}$ and $\mathrm{R}_{\text {standard }}$ are the ${ }^{13} \mathrm{C}:{ }^{12} \mathrm{C}$ or ${ }^{15} \mathrm{~N}:{ }^{14} \mathrm{~N}$ ratios of the sample and standard respectively. The standards are Vienna Pee Dee Belemnite limestone (VPDB) for carbon, and atmospheric $\mathrm{N}_{2}$ for nitrogen. The units are expressed as parts per thousand or per mille (ppt, \%o). The within-run standard deviation (SD) of an acetanilide standard was $\leq 0.2 \%$ for both $\delta^{13} \mathrm{C}$ and $\delta^{15} \mathrm{~N}$ values. We also measured the weight-percent
$[\mathrm{C}] /[\mathrm{N}]$ ratios of each sample, which were in the expected range (2.8 to 3.5) for pure protein (Ambrose 1990) (see Table 1).

Data treatment. A Kolmogorov-Smirnov test was employed to test normality for the 2 variables $\left(\delta^{13} \mathrm{C}\right.$, $\delta^{15} \mathrm{~N}$ ) and an $F$-test was used to test homogeneity of variance within a species. Because the data did not meet the requirements for parametric statistical tests, differences in $\delta^{13} \mathrm{C}$ and $\delta^{15} \mathrm{~N}$ values among species were assessed using a nonparametric Kruskal-Wallis test $(\mathrm{K}-\mathrm{W})$, followed by the Mann-Whitney $U$-test. Differences in $\delta^{13} \mathrm{C}$ and $\delta^{15} \mathrm{~N}$ variance among species were assessed with an F-test as a way to evaluate trophic segregation/overlap among species. For all calculations, we tested significance at the $\alpha=0.05$ level.

A cluster analysis was also used to identify isotopic patterns among species and determine general trophic relationships. This approach created 1 cluster from the 9 observations supplied. The clusters are groups of observations with similar characteristics based on ${ }^{13} \mathrm{C}$ and ${ }^{15} \mathrm{~N}$ stable isotope values. To create the clusters, we used the nearest-neighbor method and Euclidean distances.

Using the groups identified in the cluster analysis, we estimated trophic level for each species using $\delta^{15} \mathrm{~N}$ values from individual specimens. Many studies have reported a correlation between the trophic level that the organism occupies and its $\delta^{15} \mathrm{~N}$ value (DeNiro \& Epstein 1981, Vander Zanden \& Rasmussen 1996). Since most marine mammals are considered top predators in the ecosystems they inhabit, we expected that the species analyzed here would occupy between the third and fifth trophic level, as they do in other regions (Pauly et al. 1998). We assumed a mean trophic discrimination factor of $3.4 \%$ per trophic level (Post 2002). The mean $( \pm \mathrm{SD}) \delta^{15} \mathrm{~N}$ value of euphausiids, from $E u$ phausia lucens $\left(\delta^{15} \mathrm{~N}=7.3 \pm 0.8 \%\right.$ ) reported by Ciancio et al. (2008) in southern Patagonian waters, was considered to be the baseline for the trophic-level calculation; in this case euphausiids are assumed to occupy a trophic level of 2. The trophic level of each individual $\left(\mathrm{TL}_{\mathrm{cet}}\right)$ was then calculated by using the equation:

$$
\mathrm{TL}_{\text {cet }}=\left(\left(\delta^{15} \mathrm{~N}_{\text {cet }}-\delta^{15} \mathrm{~N}_{\text {baseline }}\right) / 3.4\right)+2
$$

where $\delta^{15} \mathrm{~N}_{\text {cet }}$ is the nitrogen stable isotope composition of that individual and $\delta^{15} \mathrm{~N}_{\text {baseline }}$ is the nitrogen isotope composition of the baseline considered. By estimating trophic level for each specimen we could determine the mean trophic level and associated variation for each species/group in our study.

Lastly, since some of the cetacean specimens represent historic samples, we calculated a Suess correction for each specimen that accounts for the global decrease in the ${ }^{13} \mathrm{C}$ content of atmospheric $\mathrm{CO}_{2}$ that is largely due to the burning of fossil fuels over the last 
150 yr (Leuenberger et al. 1992, Indermühle et al. 1999, Francey et al. 1999). We used a time-dependent correction of $-0.022 \% \mathrm{yr}^{-1}$ and found a mean $( \pm \mathrm{SD})$ correction of only $0.5 \pm 0.1 \%$ o for each species (range: 0.4 to $0.7 \%$ ). Given the similar magnitude and small overall range in the calculated Suess corrections among species, which results in small changes (0.2 to $0.3 \%$ ) in their mean $\delta^{13} \mathrm{C}$ values relative to one another in isotopic space (see Fig. 2), we did not apply the Suess corrections to measured $\delta^{13} \mathrm{C}$ values.

\section{RESULTS}

\section{Cetacean samples}

A comparison of stable isotope values of 8 small cetacean species from Tierra del Fuego yielded significant differences in $\delta^{13} \mathrm{C}(\mathrm{K}-\mathrm{W}, \mathrm{p}<0.0001)$ and $\delta^{15} \mathrm{~N}$ values (K-W, p < 0.0001) (Fig. 2, Table 1). Overall, there was a high degree of inter-specific variation in isotope values, with means ranging from -22.8 to $-6.7 \%$ for $\delta^{13} \mathrm{C}$ and from 7.6 to $22.1 \%$ o for $\delta^{15} \mathrm{~N}$. The highest mean $\delta^{13} \mathrm{C}$ and $\delta^{15} \mathrm{~N}$ values belong to Lagenorhynchus australis, a coastal species. We found significant differences between $L$. australis and the other species in terms of $\delta^{13} \mathrm{C}$ and $\delta^{15} \mathrm{~N}$ values ( $U$-test, $\mathrm{p}<0.05)$. Two other species (Cephalorhynchus commersonii and Phocoena spinipinnis), which are believed to be coastal inhabitants, had $\delta^{13} \mathrm{C}$ and $\delta^{15} \mathrm{~N}$ values between that of $L$. australis and the offshore species (Grampus griseus, Lissodelphis peronii, and Pseudorca crassidens).

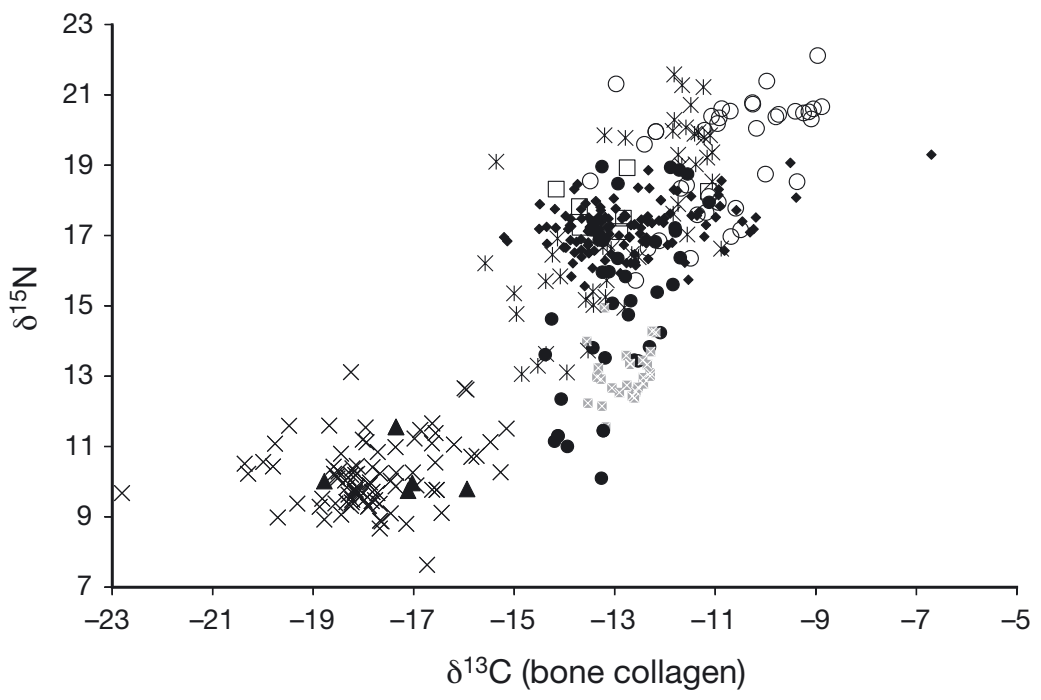

Fig. 2. Bone-collagen $\delta^{13} \mathrm{C}$ and $\delta^{15} \mathrm{~N}$ values for Cephalorhynchus commersonii $(\bullet)$, Grampus griseus (*), Lagenorhynchus australis (०), Lagenorhynchus cru-

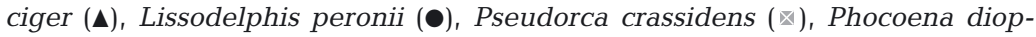
trica $(\times)$, and Phocoena spinipinnis $(\square)$
The lowest $\delta^{13} \mathrm{C}$ and $\delta^{15} \mathrm{~N}$ values were observed in Lagenorhynchus cruciger and Phocoena dioptrica, 2 species that inhabit offshore waters and are commonly seen at the Antarctic Convergence located between 50 and $60^{\circ} \mathrm{S}$. There were no significant differences in $\delta^{13} \mathrm{C}$ and $\delta^{15} \mathrm{~N}$ values between $L$. cruciger and $P$. dioptrica ( $U$-test, $\mathrm{p}=0.2182$ and $\mathrm{p}=0.8363$, respectively), but they were significantly different from the other species in both $\delta^{13} \mathrm{C}$ and $\delta^{15} \mathrm{~N}$ values ( $U$-test, $\mathrm{p}<0.05$ ).

Among the offshore inhabitants, stock assessments suggest that Grampus griseus occurs as a single population in the southwest South Atlantic, but the stableisotope data revealed a bimodal distribution. As such, we treated them as 2 separate ecotypes (GG1 and GG2) with significantly different mean $\delta^{13} \mathrm{C}$ and $\delta^{15} \mathrm{~N}$ values ( $U$-test, $\mathrm{p}<0.05)$. In general, these 2 ecotypes were significantly different from the other dolphins in both $\delta^{13} \mathrm{C}$ and $\delta^{15} \mathrm{~N}(U$-test, $\mathrm{p}<0.05)$ with a few exceptions. GG1 had $\delta^{15} \mathrm{~N}$ values similar to Lagenorhynchus australis ( $U$-test, $\mathrm{p}=0.7430$ ), while $\mathrm{GG} 2$ had $\delta^{13} \mathrm{C}$ and $\delta^{15} \mathrm{~N}$ values similar to that of Phocoena spinipinnis and Lissodelphis peronii respectively ( $U$-test, p $>0.05$; Figs. 2, 3 \& 4).

We found no significant differences in $\delta^{13} \mathrm{C}$ values between Cephalorhynchus commersonii and Phocoena spinipinnis ( $U$-test, $\mathrm{p}=0.4825$ ), but these species had significantly different $\delta^{15} \mathrm{~N}$ values ( $U$-test, $\mathrm{p}=$ 0.0266). We found no significant differences in $\delta^{13} \mathrm{C}$ values between Lissodelphis peronii and Pseudorca crassidens ( $U$-test, $\mathrm{p}=0.77$ ), but they also differed significantly in $\delta^{15} \mathrm{~N}(U$-test, $\mathrm{p}=0.0000)$.

\section{Prey samples}

Isotope data for possible prey species are presented in Fig. 5 and summarized in Table 2. In Fig. 5, isotope values for prey samples have been corrected for trophic discrimination to allow for direct comparison between isotopic data for consumers and their potential food sources. Since the isotopic discrimination varies as a function of tissue type (Hobson \& Clark 1992, Hobson et al. 1993, Caut et al. 2009, Newsome et al. 2010), we applied different corrections to prey muscle, bone, and beak values. For prey muscle, we applied a correction of $+5 \%$ and $+3.4 \%$ o to measured $\delta^{13} \mathrm{C}$ and $\delta^{15} \mathrm{~N}$ values, respectively, to account for both tissue-specific and trophic discrimination (Hare et al. 1991, Hedges et al. 2005, Koch 2007). For bone and beak samples that only re- 


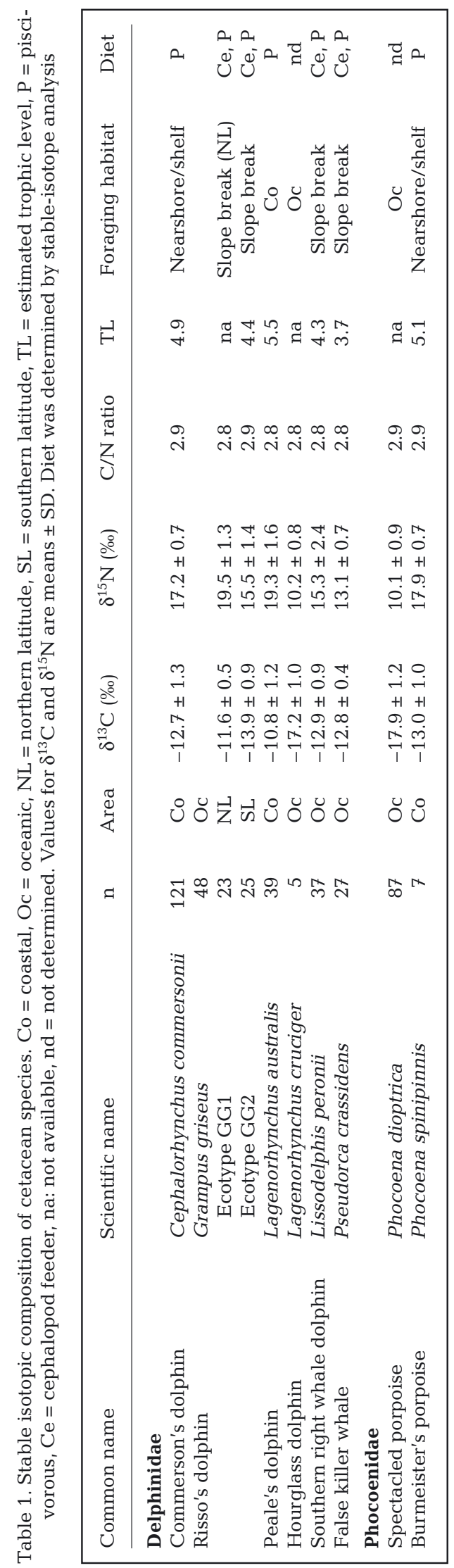

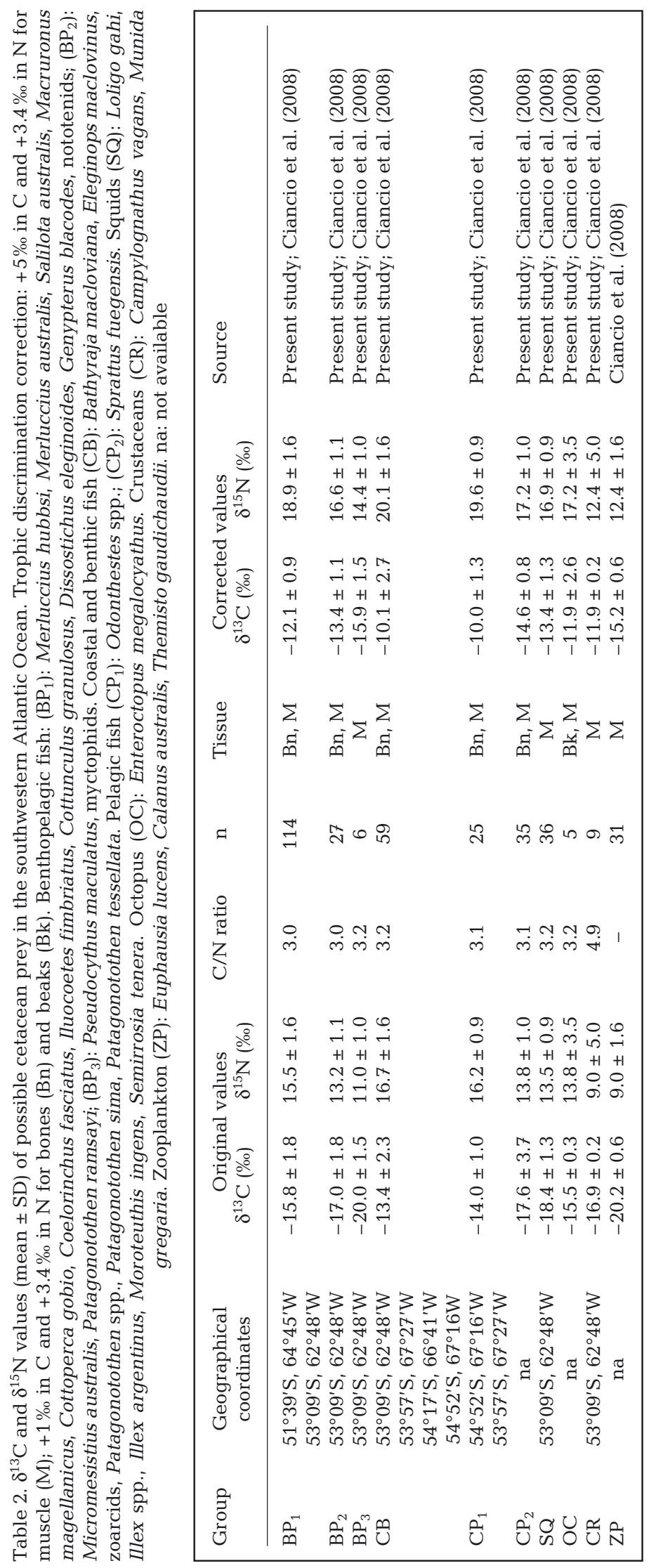




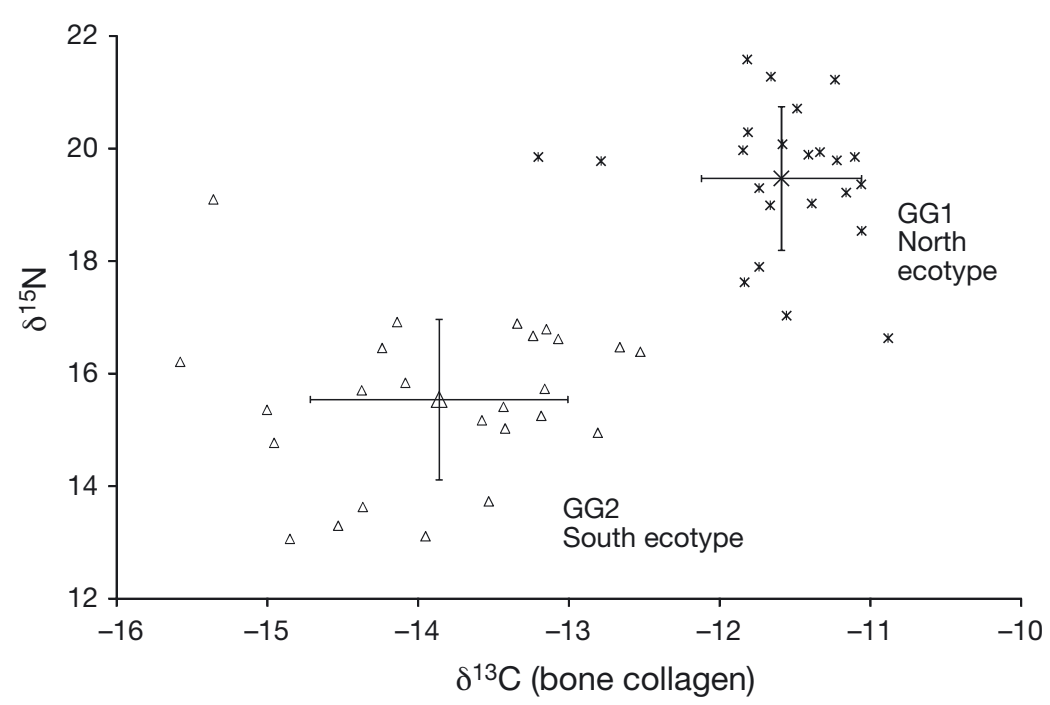

Fig. 3. Bone-collagen $\delta^{13} \mathrm{C}$ and $\delta^{15} \mathrm{~N}$ values of 2 Grampus griseus ecotypes proposed: GG1 $(*)$, the northern ecotype, and GG2 $(\Delta)$, the southern. Both can be considered offshore predators that inhabit the continental slope with movements to the shelf but at different latitudes. Values are shown for each individual animal and mean values $( \pm \mathrm{SD})$ for each ecotype

quired a correction for trophic discrimination, we applied a correction of $+1.0 \%$ and $+3.4 \%$ to measured $\delta^{13} \mathrm{C}$ and $\delta^{15} \mathrm{~N}$ values respectively (DeNiro \& Epstein 1978, 1981, Minagawa \& Wada 1984, Post 2002). The isotopic values of potential prey varied widely, with means ranging from -21.9 to $-9.2 \%$ for $\delta^{13} \mathrm{C}$ and from 2.4 to $18.6 \%$ for $\delta^{15} \mathrm{~N}$. Due to significant differences in isotope values, pelagic (CP) and benthopelagic fish (BP) were divided into $2\left(\mathrm{CP}_{1}\right.$ and $\left.\mathrm{CP}_{2}\right)$ and $3\left(\mathrm{BP}_{1}, \mathrm{BP}_{2}\right.$, and $\mathrm{BP}_{3}$ ) groups respectively, increasing the overall number of prey groups from 7 to 10 . The 10 isotopically distinct prey groups were significantly different in both mean $\delta^{13} \mathrm{C}(\mathrm{K}-\mathrm{W}, \mathrm{p}<0.0001)$ and $\delta^{15} \mathrm{~N}$ values (K-W, p < 0.0001). Coastal and benthic prey had the highest $\delta^{13} \mathrm{C}$ and $\delta^{15} \mathrm{~N}$ values, while the zooplankton group had the lowest mean values for both isotopes. Benthopelagic and pelagic species (including squid, octopus, and crustaceans) had intermediate values.

\section{Cluster analysis}

The cluster analysis (nearest neighbor) identified distinct groups among the cetacean species using $\delta^{13} \mathrm{C}$ and $\delta^{15} \mathrm{~N}$ values (Fig. 4). No major differences were found between this clustering method and a Euclidean distance metric or any other clustering algorithms. The cluster analysis shows an isotopic continuum from coastal species (Lagenorhynchus australis) with the highest mean $\delta^{13} \mathrm{C}$ and $\delta^{15} \mathrm{~N}$ values, to oceanic species with the lowest isotope values (Lagenorhynchus cruciger and Phocoena dioptrica) (Fig. 5). Specifically, the cluster analysis identified 4 main groups of species in the data set: (1) coastal species (Lagenorhynchus australis and possibly northern Grampus griseus ecotype GG1), (2) nearshore-Patagonian shelf species (Cephalorhynchus commersonii and Phocoena spinipinnis), (3) Patagonian shelf-slope species (GG2, Lissodelphis peronii, and Pseudorca crassidens), and (4) oceanic and cold water species (Lagenorhynchus cruciger and Phocoena dioptrica). We consider Groups 1 (except for GG1) and 2 to be inshore species and Groups 3 and 4 offshore species (Figs. 4 \& 5).

Trophic-level estimates from Eq. (2) ranged from 3.7 to 5.5 (Table 1). We estimated trophic level for only 6 species. We were unable to estimate the trophic levels for Phocoena dioptrica, Lagenorhynchus cruciger, and the GG1 ecotype as there was no isotopic data available for possible prey items or primary producers in the areas where they generally forage.

There were no differences in inter-specific isotopic variance for $\delta^{13} \mathrm{C}(F=0.6375, \mathrm{p}=0.3)$ and $\delta^{15} \mathrm{~N}(F=$ $0.9163, \mathrm{p}=0.5142$ ) among Cephalorhynchus commersonii and Phocoena spinipinnis, but we did find a significant difference in trophic level between these species $(U$-test, $\mathrm{p}=0.0317)$. This latter finding should be interpreted with caution due to the low number of $P$. spinipinnis available for analysis $(\mathrm{n}=7)$. We found significant differences in $\delta^{15} \mathrm{~N}$ variation among the 3 offshore species (Lissodelphis peronii, Pseudorca crassidens, GG2). L. peronii had a significantly higher degree of $\delta^{15} \mathrm{~N}$ variation than GG2 and P. crassidens $(F=0.3425, \mathrm{p}=0.0037$ for $L$. peronii and GG2; $F=0.0892, \mathrm{p}=0.0000$ for $L$. peronii and P. crassidens); GG2 also had a higher degree of variation in $\delta^{15} \mathrm{~N}$ than P. crassidens $(F=0.2604, \mathrm{p}=0.0006)$. We also found significant differences in the degree of $\delta^{13} \mathrm{C}$ variation between $P$. crassidens and $L$. peronii or GG2. L. peronii and GG2 had a higher degree of $\delta^{13} \mathrm{C}$ variation than $P$. crassidens $(F=0.2576, \mathrm{p}=0.0003$ for $L$. peronii and $P$. crassidens; $F=0.2484, \mathrm{p}=0.0004$ for GG2 and $P$. crassidens), but there was no significant difference in $\delta^{13} \mathrm{C}$ variation between GG2 and $L$. peronii $(F=0.9644, \mathrm{p}=$ 0.4516). For trophic level, there was no significant difference between GG2 and L. peronii ( $U$-test, $\mathrm{p}=$ $0.9714)$, but there were statistical differences between these species and P. crassidens ( $U$-test, $\mathrm{p}<0.05)$. Finally, there were no significant differences in $\delta^{13} \mathrm{C}(F=$ $0.749, \mathrm{p}=0.4386)$ and $\delta^{15} \mathrm{~N}(F=0.702, \mathrm{p}=0.4073)$ variance between Phocoena dioptrica and Lagenorhynchus cruciger. 


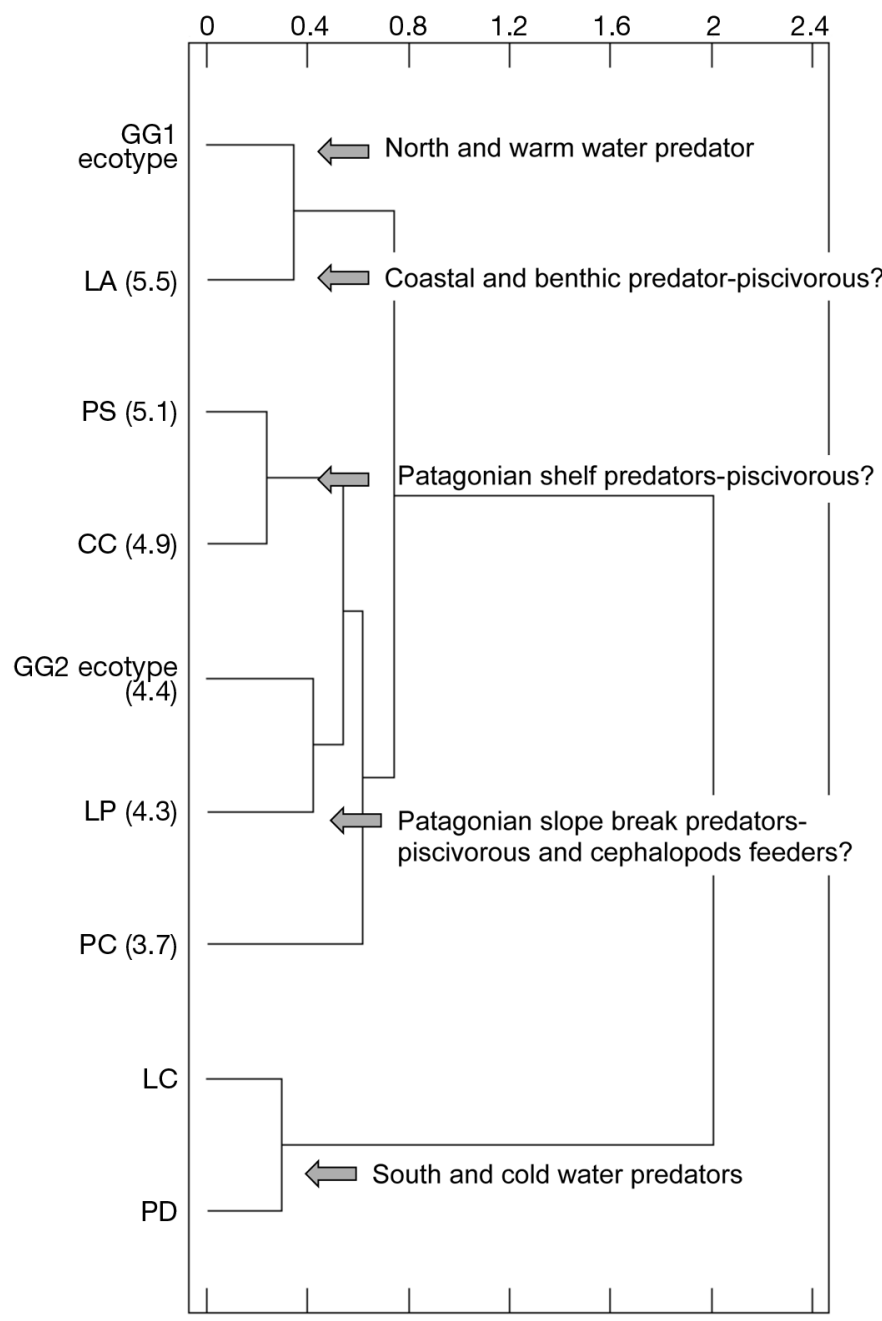

Fig. 4. Clustering analysis (nearest-neighbor method and Euclidean distances) for Cephalorhynchus commersonii (CC), GG1 and GG2 ecotypes of Grampus griseus, Lagenorhynchus australis (LA), Lagenorhynchus cruciger (LC), Lissodelphis peronii (LP), Pseudorca crassidens (PC), Phocoena dioptrica (PD), and Phocoena spinipinnis (PS). The $x$-axis represents the distance metric (Euclidean). The number in parentheses is the estimated trophic level (not estimated for LC, PD, and GG1 ecotype due to lack of potential prey or food base isotope data)

\section{DISCUSSION}

\section{Spatial foraging areas}

The large variation in mean bone-collagen $\delta^{13} \mathrm{C}$ and $\delta^{15} \mathrm{~N}$ observed among oceanic and nearshore cetaceans (Fig. 5) likely reflects latitudinal and longitudinal isotopic gradients in primary producers. These spatial baseline isotopic gradients have been observed in other regions such as the North Pacific Ocean (Rau et al. 1982, Dunton et al. 1989, France 1995, Schell et al. 1998, Montoya 2007). We found a significant decrease in mean $\delta^{13} \mathrm{C}$ values from species that primarily inhabit coastal to oceanic areas (longitudinal variation) and from species that inhabit northern to southern areas (latitudinal variation). Specifically, we found a difference of $\sim 2.0 \%$ in $\delta^{13} \mathrm{C}$ values between Groups 1 and 2 and a difference of $2.4 \%$ between Groups 1 and 3 (Figs. 4 \& 5). Oceanic species (Group 4) showed the largest difference in mean $\delta^{13} \mathrm{C}$ values, and had mean $\delta^{13} \mathrm{C}$ values that were $6.8,4.7$, and $4.4 \%$ lower than Groups 1, 2, and 3, respectively.

We also found a decrease in $\delta^{15} \mathrm{~N}$ values as a function of latitude and longitude. $\delta^{15} \mathrm{~N}$ values are strongly influenced by trophic position, which can complicate their use as habitat proxies; however, we found similar geographical patterns in $\delta^{15} \mathrm{~N}$ and $\delta^{13} \mathrm{C}$. We observed a difference in $\delta^{15} \mathrm{~N}$ of $\sim 2.0 \%$ between the coastal group (Group 1) and the nearshore-shelf species (Group 2). An even larger difference of $\sim 5.0 \%$ was observed between the coastal group and Patagonian shelf-slope boundary species (Group 3). Finally, isotopic differences were larger when both longitudinal and latitudinal variation was considered, with differences up to 9.1, 7.4, and $4.5 \%$ in mean $\delta^{15} \mathrm{~N}$ values between the southern oceanic group (Group 4) and Groups 1, 2, and 3.

Differences in both $\delta^{13} \mathrm{C}$ and $\delta^{15} \mathrm{~N}$ values between inshore and offshore groups confirm that an isotopic approach can be used to differentiate the spatial foraging areas of cetacean species along a longitudinal gradient in this region of the southwest Atlantic Ocean. We found differences of similar magnitude in both $\delta^{13} \mathrm{C}$ and $\delta^{15} \mathrm{~N}$ values between the oceanic species and the other 3 groups (coastal, nearshore, and slope-break species). This confirms that both isotopic systems can be used to determine latitudinal variation in the foraging habitats of these top predators, which ultimately reflects the variation at the base of the food webs in the study region.

Similarities in baseline values of different habitats, however, can complicate interpretation of prey and habitat preferences. For example, Lagenorhynchus australis and Grampus griseus ecotype GG1 have similar mean isotope values, which suggest that these species consume similar types of prey in the same habitat. L. australis and GG1, however, are known to have completely different prey preferences and occupy different habitats (see 'Trophic level and foraging behavior'). This example shows that, in some cases, isotopic data should be complemented with ecological information obtained from direct observation or gut/stomach content analysis. Such comparisons may help elucidate whether the differences or similarities observed among groups or species are driven by baseline isotopic gradients or differences in their ecology (prey or habitat preferences).

Isotopic variance can also be used to measure the foraging niche width (Bearhop et al. 2004). Isotope val- 


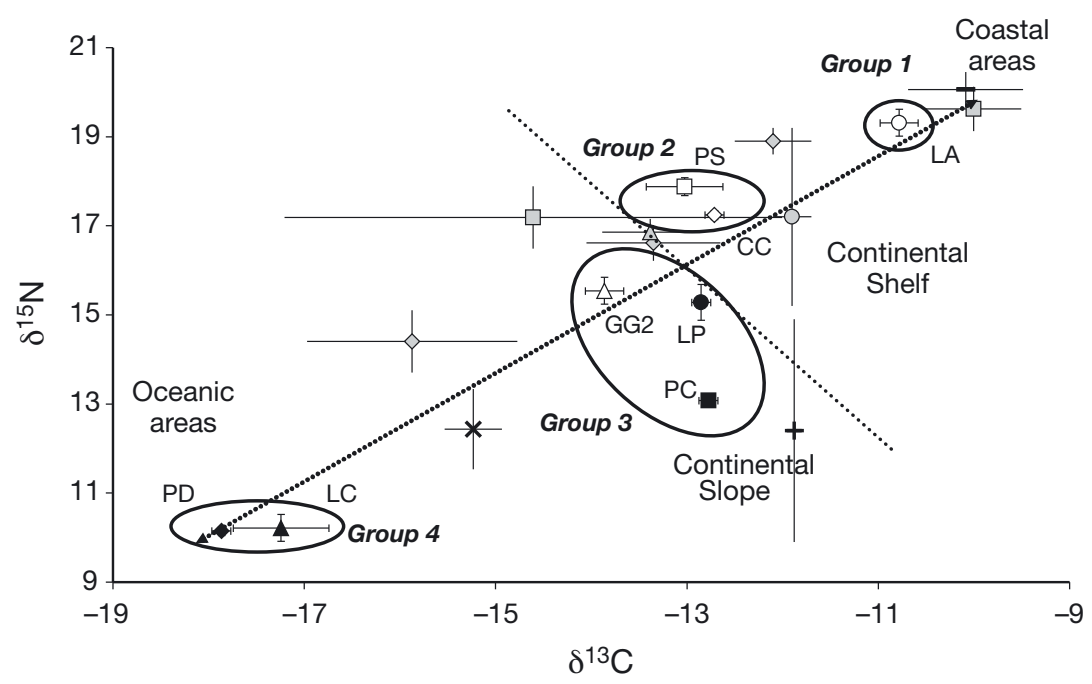

Fig. 5. Stable isotope trends, visualizing the main trophic behavior of the 8 species of small cetaceans, from the coastal to the oceanic realm. $\delta^{13} \mathrm{C}$ and $\delta^{15} \mathrm{~N}$ mean values $( \pm \mathrm{SE})$ are shown for the cetacean species and potential prey. The northern ecotype (GG1) of Grampus griseus is not shown here. Oval outlines indicate main foraging habitats. Group 1, coastal species: Lagenorhynchus australis (LA, O). Group 2, nearshore-shelf species: Cephalorhynchus commersonii $(\mathrm{CC}, \diamond)$, Phocoena spinipinnis (PS, $\square)$. Group 3, slope-break species: Lissodelphis peronii $(\mathrm{LP}, \bullet), G$. griseus $\mathrm{GG} 2$ ecotype $(\triangle)$, Pseudorca crassidens $(\mathrm{PC}, \mathbf{\square})$. Group 4, oceanic species: Phocoena dioptrica (PD, $\bullet$ ), Lagenorhynchus cruciger $(L C, \mathbf{\Delta})$. Prey data: coastal benthic prey species $(-)$, demersal or benthopelagic prey species from the shelf $(\diamond)$, pelagic prey species $(\square)$, squids $(\Delta)$, octopus $(O)$, crustaceans $(\boldsymbol{+})$, and zooplankton $(\times)$. Mean prey values are shown shifted to approximate trophic discrimination. Thicker dotted line: isotopic continuum from coastal to oceanic species; thinner dotted line: division between inshore and offshore species

ues of some cetacean species overlapped with values of others, which indicates a potential overlap in their foraging areas and/or prey preferences.

\section{Trophic level and foraging behavior}

\section{Inshore species}

Lagenorhynchus australis had the highest mean $\delta^{13} \mathrm{C}$ and $\delta^{15} \mathrm{~N}$ values, suggesting that it forages in coastal ecosystems and occupies a relatively high trophic level $(\sim 5.5$; Table 1$)$ in comparison to the other inshore species (Cephalorhynchus commersonii and Phocoena spinipinnis). L. australis lives in a habitat where macroalgae, which typically have $\delta^{13} \mathrm{C}$ values 6 to $8 \%$ higher than sympatric phytoplankton (France 1995), are important primary producers. Comparison of mean L. australis isotope values with that of potential prey suggests that coastal-benthic species (e.g. zoarcids, Patagonotothen sima, Patagonotothen tessellata, Eleginops maclovinus) and nearshore pelagic species (e.g. Odonthestes spp.) are important food sources for L. australis.
Cephalorhynchus commersonii and Phocoena spinipinnis are also considered to be nearshore species. Similarities in $\delta^{13} \mathrm{C}$ values among C. commersonii, $P$. spinipinnis, Lissodelphis peronii, Pseudorca crassidens, and the Grampus griseus GG2 ecotype suggest that their prey preferences or foraging habitat overlaps and likely is centered on the Patagonian shelf. C. commersonii and $P$. spinipinnis have similar mean $\delta^{13} \mathrm{C}$ and $\delta^{15} \mathrm{~N}$ values (Fig. 4) and occupy a similar trophic level, suggesting that they have similar prey and habitat preferences, perhaps competing for food sources in nearshore coastal ecosystems. Brownell $\&$ Praderi (1982) suggest that $P$. spinipinnis is less abundant on the Atlantic coast than the Pacific because of competition with other small coastal cetaceans such as tucuxi dolphin Sotalia fluviatilis and La Plata dolphin Pontoporia blainvillei in the north, and C. commersonii and Lagenorhynchus australis in the south. $C$. commersonii and P. spinipinnis, however, had different mean $\delta^{13} \mathrm{C}$ and $\delta^{15} \mathrm{~N}$ values than $L$. australis, suggesting that they are not in direct competition for food or habitat with the coastal L. australis.

Conventional diet analysis (Bastida et al. 1988, Escare \& Oporto 1992) has revealed that Cephalorhynchus commersonii and Phocoena spinipinnis are opportunistic coastal feeders in the shallow waters of the continental shelf. In agreement with conventional analysis, our data suggest that C. commersonii and P. spinipinnis may spend a lot of time over the Patagonian shelf pursuing pelagic (e.g. Odonthestes spp. and Sprattus fuegensis) and benthopelagic fish (e.g. Merluccius hubbsi, Merluccius australis, Salilota australis, notothenids, Micromesistius australis, Genypterus blacodes) and may occasionally forage in deeper waters over the continental shelf for other pelagic prey types, such as squid (e.g. Illex argentinus, Loligo gahi).

\section{Offshore species}

Pseudorca crassidens was previously considered an oceanic predator (Best 2007), but similarities in mean $\delta^{13} \mathrm{C}$ values with other offshore species (Grampus griseus ecotype GG2 and Lissodelphis peronii) suggest that $P$. crassidens principally occupies habitat along the continental shelf-slope boundary at approximately the same latitude as the animals stranded ( 52 to $55^{\circ} \mathrm{S}$ ) 
(Fig. 5). P. crassidens is known for its mass strandings, including an event in which 181 animals stranded in the Strait of Magellan in 1989 (Koen Alonso et al. 1999, Goodall et al. 2008). The stomach contents of 25 individuals from that stranding primarily contained neriticoceanic squid and neritic fish commonly found on the Patagonian shelf and adjacent offshore waters (Koen Alonso et al. 1999). P. crassidens may differ from L. peronii and the GG2 ecotype by specializing on cephalopods, as previous stomach-content analysis has shown (Koen Alonso et al. 1999). This is supported by the estimated trophic level (and associated mean $\delta^{15} \mathrm{~N}$ value) of $P$. crassidens, which was the lowest of any species for which trophic level could be calculated (Table 1). The relatively low isotopic variation in both $\delta^{13} \mathrm{C}$ and $\delta^{15} \mathrm{~N}$ observed for $P$. crassidens also suggest that it may be a foraging specialist. Because of the limited number of squid in our prey data set, we could not identify a probable prey species for P. crassidens (Fig. 5).

Lissodelphis peronii is considered an oceanic and circumpolar predator (Best 2007). Our results suggest that similar to Pseudorca crassidens and GG2, L. peronii is an offshore species that primarily inhabits waters over the continental shelf-slope boundary (Fig. 5). But similarities in mean $\delta^{13} \mathrm{C}$ values with nearshore species (Cephalorhynchus commersonii and Phocoena spinipinnis) suggest that they also spend time foraging over the Patagonian shelf. In other parts of the world, L. peronii is often observed in nearshore habitats, such as the western margins of South Africa and Chile, foraging in the Benguela and Humboldt Current systems (Best 2007), respectively, but there is no information on specific movements of this dolphin in the southwestern South Atlantic.

Lissodelphis peronii stomach contents from Chile and Peru suggest that it preys at night on a variety of pelagic squid and fish (Torres \& Aguayo 1979, Van Waerebeek \& Oporto 1990). The mean $\delta^{15} \mathrm{~N}$ value for L. peronii was intermediate between values for species that primarily feed on squid (Pseudorca crassidens) and species that primarily consume fish (Phocoena spinipinnis and Cephalorhynchus commersonii), suggesting a mixed diet of fish (e.g. Micromesistius australis, notothenids, Coelorinchus fasciatus, Iluocoetes fimbriatus) and cephalopods (e.g. Illex argentinus, Loligo gahi, Moroteuthis ingens) taken primarily over the Patagonian shelf-slope boundary.

Grampus griseus is known to inhabit the southwestern South Atlantic, but has not been well studied in this region. Initially, we assumed that all of the G. griseus individuals analyzed in the present study were sourced from one population, since they all stranded in a relatively small area, but our analyses show a bimodal distribution in mean $\delta^{13} \mathrm{C}$ and $\delta^{15} \mathrm{~N}$ val- ues (Fig. 2). Therefore, we have treated them as 2 distinct groups, GG1 and GG2, with high and low mean $\delta^{13} \mathrm{C}$ and $\delta^{15} \mathrm{~N}$ values, respectively. We considered GG1 as the northern group, with mean values of $\delta^{13} \mathrm{C}$ and $\delta^{15} \mathrm{~N}$ similar to those of Lagenorhynchus australis (see 'Cluster analysis' above), whereas values for GG2 were more similar to species (Lissodelphis peronii and Pseudorca crassidens) that principally occupy southern areas (Fig. 3). Both groups (GG1 and GG2) likely inhabit the continental shelf-slope break in the southwestern South Atlantic, which contrasts with other studies that report G. griseus occupying deep water and oceanic habitats (Olavarría et al. 2001, Davis et al. 2002). There are no dietary data based on stomach contents of this species off southernmost South America, but off South Africa, G. griseus primarily forages on cephalopods (Sekiguchi et al. 1992). Our data suggest that the southern ecotype (GG2) has a similar trophic behavior to L. peronii and P. crassidens, primarily consuming cephalopods (e.g. Semirrosia tenera, Moroteuthis ingens, Loligo gahi, Illex argentinus) and some pelagic/benthopelagic fish (e.g. Micromesistius australis, Sprattus fuegensis, myctophids) (Fig. 5).

\section{Oceanic species}

Found only in the Southern Hemisphere north and south of the Antarctic Convergence, Lagenorhynchus cruciger is often sighted at sea, but little is known about its prey preferences. From the few samples gathered from stomach-content analysis, it has been suggested that this species feeds on fish and squid that undertake diurnal migrations from deep water to the surface (Goodall et al. 1997b, Fernández et al. 2003). In addition, little ecological information exists for Phocoena dioptrica, which is one of the world's rarest cetaceans that occasionally strands on coasts adjacent to the southwestern Atlantic Ocean, especially Tierra del Fuego. It has also been sighted in southern circumpolar and subantarctic oceanic waters south of New Zealand near the Polar Front $\left(\sim 64^{\circ} \mathrm{S}\right)$ (Goodall \& Schiavini 1995, Sekiguchi et al. 2006). L. cruciger and $P$. dioptrica had the lowest mean $\delta^{13} \mathrm{C}$ and $\delta^{15} \mathrm{~N}$ values, which suggests that they inhabit cold, oceanic waters of the Antarctic Convergence (Rau et al. 1982, Goericke \& Fry 1994, Dehairs et al. 1997). Unfortunately, we have no data for potential prey of these species due to logistical difficulties in sampling at the Polar Front. Assessing spatial gradients in baseline and primary producer isotope values and confirming the latitudinal and longitudinal decline in both $\delta^{13} \mathrm{C}$ and $\delta^{15} \mathrm{~N}$ values inferred from data for top predators reported here is needed. These samples will be important for determining the roles of several offshore cetacean species in 
the Southern Ocean (e.g. L. cruciger, P. dioptrica, and Pseudorca crassidens) for which little ecological information currently exists.

\section{Summary}

We found significant isotopic differences in $\delta^{13} \mathrm{C}$ and $\delta^{15} \mathrm{~N}$ values among the 8 cetacean species that likely relate to differences in habitat use and trophic level information that has been obtained from traditional techniques (e.g. gut/stomach contents and observation). In cases where previously published stomach-content and observational data are unreliable due to low sample sizes, our data provide new insight into the ecology of some species, including Phocoena dioptrica, Lagenorhynchus cruciger, and Phocoena spinipinnis. Although the combined use of both $\delta^{13} \mathrm{C}$ and $\delta^{15} \mathrm{~N}$ revealed spatial information on feeding location and food habits, in some cases isotopic data alone were unable to discriminate among species that obviously have different ecologies (e.g. Lagenorhynchus australis and Grampus griseus ecotype GG1). Similar to other well-studied systems (e.g. North Pacific Ocean), the $\delta^{13} \mathrm{C}$ and $\delta^{15} \mathrm{~N}$ values of top consumers in the western South Atlantic are dependent on spatial variations in $\delta^{13} \mathrm{C}$ and $\delta^{15} \mathrm{~N}$ values of primary producers in different habitats (e.g. coastal, continental shelf, Antarctic Convergence). The influence of ${ }^{13} \mathrm{C}$-enriched macroalgae on coastal food webs is likely responsible for the relatively high mean $\delta^{13} \mathrm{C}$ values of $L$. australis in comparison to other cetaceans that forage in pelagic habitats (e.g. continental shelf, shelf-slope break, Antarctic Convergence) where macroalgae dominate primary production. $\delta^{15} \mathrm{~N}$ values reflect a combination of diet and habitat use. L. australis has relatively high $\delta^{15} \mathrm{~N}$ values in comparison to other species, consistent with what would be expected of a coastal benthic forager. Cephalorhynchus commersonii and $P$. spinipinnis have similar isotope values and calculated trophic levels indicative of a piscivorous diet from the continental shelf, which supports previous notions of possible competition for food and/or habitat among these species. Lissodelphis peronii and G. grise$u s$, which are considered to principally consume squid and fish, have similar mean $\delta^{15} \mathrm{~N}$ values and likely occupy similar trophic levels. L. peronii and G. griseus have intermediate isotope values between Pseudorca crassidens and the inshore species (C. commersonii, $P$. spinipinnis, and Lagenorhynchus australis). The lowest values of $\delta^{13} \mathrm{C}$ and $\delta^{15} \mathrm{~N}$ from $P$. dioptrica and L. cruciger reflect their oceanic habitat near the Antarctic Convergence. Furthermore, the bimodal distribution found among G. griseus individuals suggests the existence of a previously unrecognized subdivision among populations in the western South Atlantic.
Acknowledgments. We thank A. J. Figini, J. Carbonari, R. Huarte, S. Favoretti, and R. Bastida for giving their help during different steps of the study. We also thank the Carnegie Institution of Washington and the W. M. Keck Foundation for financial support, and W. Wurzel for technical assistance. Centro Austral de Investigaciones Científicas (CADIC) and Museo Acatushún de Aves y Mamíferos Marinos Australes gave us support. A. C. Jakle and N. A. Dellabianca provided constructive reviews. We especially appreciate the hard work of volunteers who located strandings and cleaned specimens in Tierra del Fuego over the past 3 decades. L.R.'s research was carried out under a $\mathrm{PhD}$ fellowship from Consejo Nacional de Investigaciones Científicas y Técnicas of Argentina (CONICET), and funded by grants from Cetacean Society International (CSI), Sigma-Xi Committee on Grantsin-Aid of Research, and Conservation and Research and Education Opportunities (CREO).

\section{LITERATURE CITED}

Ambrose SH (1990) Preparation and characterization of bone and tooth collagen for isotopic analysis. J Archaeol Sci 17: $431-451$

Aurioles D, Koch PL, Le Boeuf BJ (2006) Differences in foraging location of Mexican and California elephant seals: evidence from stable isotopes in pups. Mar Mamm Sci 22: 326-338

Baker A (1974) Risso's dolphin in New Zealand waters, and the identity of 'Pelorus Jack'. Rec Dom Mus 8:267-276

Baker AL (1981) The southern right whale dolphin Lissodelphis peronii (Lacépède) in australasian waters. Natl Mus NZ Rec 2:17-34

Bastida R, Lichtschein V, Goodall RNP (1988) Food habits of Cephalorhynchus commersonii off Tierra del Fuego. Rep Int Whal Comm Spec Issue 9:143-160

Baumgartner MF (1997) The distribution of Risso's dolphin (Grampus griseus) with respect to to the physiography of the northern gulf of Mexico. Mar Mamm Sci 13:614-638

Bearhop S, Adams CE, Waldron S, Fuller RA, Macleod H (2004) Determining trophic niche width: a novel approach using stable isotope analysis. J Anim Ecol 73:1007-1012

Berón Vera B, Pedraza SN, Raga JA, Gil de Pertierra A, Crespo EA, Koen Alonso M, Goodall RNP (2001) Gastrointestinal helminths of Commerson's dolphin Cephalorhynchus commersonii from central Patagonia and Tierra del Fuego. Dis Aquat Org 47:201-208

Best PB (2007) Whales and dolphins of the Southern African subregion. Cambridge University Press, Cambridge

Best PB, Schell DM (1996) Stable isotopes in southern right whale (Eubalaena australis) baleen as indicators of seasonal movements, feeding and growth. Mar Biol 124: 483-494

Brownell RL, Praderi R (1982) Status of Burmeister's porpoise, Phocoena spinipinnis, in South American waters. In: Mammals in the seas. FAO Fish Ser 5:91-96

> Brownell RL, Praderi R (1984) Phocoena spinipinnis. Mamm Species 217:1-5

Burton RK, Koch PL (1999) Isotopic tracking of foraging and long-distance migration in northeastern Pacific pinnipeds. Oecologia 119:578-585

> Caut S, Angulo E, Courchamp F (2009) Variation in discrimination factors $\left(\delta^{15} \mathrm{~N}\right.$ and $\left.\delta^{13} \mathrm{C}\right)$ : the effect of diet isotopic values and applications for diet reconstruction. J Appl Ecol 46:443-453

Ciancio JE, Pascual MA, Botto F, Frere E, Iribarne O (2008) Trophic relationships of exotic anadromous salmonids in 
the southern Patagonian shelf as inferred from stable isotopes. Limnol Oceanogr 53:788-798

Clarke M, Goodall N (1994) Cephalopods in the diets of three odontocete cetacean species stranded at Tierra del Fuego, Globicephala melaena (Traill, 1809), Hyperoodon planifrons Flower, 1882 and Cephalorhynchus commersonii (Lacépede, 1804). Antarct Sci 6:149-154

Davis RW, Ortega-Ortiz JG, Ribic CA, Evans WE and others (2002) Cetacean habitat in the northern oceanic Gulf of Mexico. Deep-Sea Res I 49:121-142

> Dehairs F, Kopczynska E, Nielsen P, Lancelot C, Bakker CE, Koeve W, Goeyens L (1997) $\delta^{13} \mathrm{C}$ of Southern Ocean suspended organic matter during spring and early summer: regional and temporal variability. Deep-Sea Res II 44: 129-142

$>$ DeNiro MJ, Epstein S (1978) Influence of diet on the distribution of carbon isotopes in animals. Geochim Cosmochim Acta 42:495-506

DeNiro MJ, Epstein S (1981) Influence of diet on the distribution of nitrogen isotopes in animals. Geochim Cosmochim Acta 45:341-351

> Drago M, Crespo EA, Aguilar A, Cardona L, García N, Dans SL, Goodall N (2009) Historic diet change of the South American sea lion in Patagonia as revealed by isotopic analysis. Mar Ecol Prog Ser 384:273-286

- Dunton KH, Saupe SM, Golikov AN, Schell DM, Schonberg SV (1989) Trophic relationships and isotopic gradients among arctic and subarctic marine fauna. Mar Ecol Prog Ser 56:89-97

Escare L, Oporto JA (1992) Alimentación de la marsopa espinosa, Phocoena spinipinnis (Burmeister, 1865) (Cetacea: Phocoenidae) en Queuele, IX Región-Chile. 5ta Reun Trab Esp Mam Acuát América del Sur, SOLAMAC, Buenos Aires, p 23

Fajardo-Mellor L, Berta A, Brownell RL, Boy CC, Goodall RNP (2006) The phylogenetic relationships and biogeography of true porpoises (Mammalia: Phocoenidae) based on morphological data. Mar Mamm Sci 22:910-932

> Fernández M, Berón-Vera B, García NA, Raga AA, Crespo EA (2003) Food and parasites from two hourglass dolphins, Lagenorhynchus cruciger (Quoy and Gaimard, 1824), from Patagonian waters. Mar Mamm Sci 19: 832-836

Forero MG, Bortolotti GR, Hobson KA, Donazar JA, Bertelotti M, Blanco G (2004) High trophic overlap within the seabird community of Argentinean Patagonia: a multiscale approach. J Anim Ecol 73:789-801

France RL (1995) Carbon-13 enrichment in benthic compared to planktonic algae: foodweb implications. Mar Ecol Prog Ser 124:307-312

Francey RJ, Allison CE, Etheridge DM, Trudinger CM and others (1999) A 1000 -year precision record of $\delta^{13} \mathrm{C}$ in atmospheric $\mathrm{CO}_{2}$. Tellus B 51:170-193

Goericke R, Fry B (1994) Variations of marine plankton $\delta^{13} \mathrm{C}$ with latitude, temperature, and dissolved $\mathrm{CO}_{2}$ in the world ocean. Global Biogeochem Cycles 8:85-90

Goodall RNP (1978) Report on the small cetaceans stranded on the coasts of Tierra del Fuego. Sci Rep Whales Res Inst 30:197-230

Goodall RNP, Galeazzi AR (1985) A review of the food habits of the small cetaceans of the Antarctic and sub-Antarctic. In: Siegfried WR, Condy PR, Laws RM (eds) Antarctic nutrient cycles and food webs. Springer Verlag, Berlin, p 566-572

Goodall RNP, Schiavini ACM (1992) Varamientos de delfín gris, Grampus griseus, en las costas del extremo sur sudamericano. 5ta Reun Esp Mam Acuát América del Sur,
SOLAMAC, Buenos Aires, p 31

Goodall RNP, Schiavini ACM (1995) On the biology of the spectacled porpoise, Australophocaena dioptrica. Rep Int Whal Comm Spec Issue 16:411-453

Goodall RNP, Schiavini ACM, Fermani C (1994) Net fisheries and net mortality of small cetaceans off Tierra del Fuego, Argentina. Rep Int Whal Comm Spec Issue 15:295-304

Goodall RNP, Norris KS, Harris G, Oporto JA, Castello HP (1995) Notes on the biology of the Burmeister's porpoise, Phocoena spinipinnis, off southern South America. Rep Int Whal Comm Spec Issue 16:317-347

Goodall RNP, Norris KS, Schevill WE, Fraga F and others (1997a) Review and update on the biology of Peale's dolphin, Lagenorhynchus australis. Rep Int Whal Comm 47: 777-796

Goodall RNP, Baker AN, Best PB, Meyer M, Miyazaki N (1997b) On the biology of the hourglass dolphin, Lagenorhynchus cruciger (Quoy and Gaimard, 1824). Rep Int Whal Comm 47:985-999

Goodall RNP, Benegas LG, Boy CC, Dellabianca N, Pimper L, Riccialdelli L (2008) Review of small cetaceans stranded or incidentally captured on the coasts of Tierra del Fuego, Argentina, over 33 years. Sci Comm Doc SC/60/SM21. International Whaling Commission, Cambridge

> Hare PE, Fogel ML, Stafford TW Jr, Mitchell AD, Hoering TC (1991) The isotopic composition of carbon and nitrogen in individual amino acids isolated from modern and fossil proteins. J Archaeol Sci 18:277-292

Hedges REM, Stevens RE, Koch PL (2005) Isotopes in bones and teeth. In: Leng MJ (ed) Isotopes in palaeoenvironmental research. Springer, Dordrecht, p 117-145

- Hobson KA, Clark RG (1992) Assessing avian diets using stable isotopes II: factors influencing diet-tissue fractionation. Condor 94:189-197

Hobson KA, Alisauskas RT, Clark RG (1993) Stable-nitrogen isotope enrichment in avian tissues due to fasting and nutritional stress: implications for isotopic analyses of diet. Condor 95:388-394

> Hobson KA, Sinclair EH, York AE, Thomason JR, Merrick RE (2004) Retrospective isotopic analyses of Steller sea lion tooth annuli and sea-bird feathers: a cross-taxa approach to investigating regime and dietary shifts in the Gulf of Alaska. Mar Mamm Sci 20:621-638

Indermühle A, Stocker TF, Joos F, Fischer H and others (1999) Holocene carbon-cycle dynamics based in $\mathrm{CO}_{2}$ trapped in ice at Taylor Dome, Antarctica. Nature 398:121-126

Koch PL (2007) Isotopic study of the biology of modern and fossil vertebrates. In: Michener R, Lajtha K (eds) Stable isotopes in ecology and environmental science. Blackwell Publishing, Malden, MA, p 99-154

Koen Alonso M, Pedraza SN, Schiavini ACM, Goodall RNP, Crespo EA (1999) Stomach contents of false killer whales (Pseudorca crassidens) stranded along the Strait of Magellan. Mar Mamm Sci 15:712-724

> Leuenberger M, Siegenthaler U, Langway CC (1992) Carbon isotope composition of atmospheric $\mathrm{CO}_{2}$ during the last ice age from an Antarctic ice core. Nature 357:488-490

Lewis R, O'Connell TCO, Lewis M, Campagna C, Hoelzel AR (2006) Sex-specific forging strategies and resource partitioning in the southern elephant seal (Mirounga leonina). Proc Biol Sci 273:2901-2907

Michener RH, Kaufman L (2007) Stable isotope ratios as tracers in marine food webs: an update. In: Michener R, Lajtha $\mathrm{K}$ (eds) Stable isotopes in ecology and environmental science. Blackwell Publishing, Malden, MA, p 238-282

> Minagawa M, Wada E (1984) Stepwise enrichment of ${ }^{15} \mathrm{~N}$ along food chains: further evidence and the relation 
between $\delta^{15} \mathrm{~N}$ and animal age. Geochim Cosmochim Acta 48:1135-1140

Montoya JP (2007) Natural abundance of ${ }^{15} \mathrm{~N}$ in marine planktonic ecosystems. In: Michener R, Lajthka K (eds) Stable isotopes in ecology and environmental science. Blackwell Publishing, Malden, MA, p 176-201

Newcomer MW, Jefferson TA, Brownell RLJ (1996) Lissodelphis peronii. Mamm Species 531:1-5

Newsome SD, Martinez del Río C, Bearhop S, Phillips DL (2007) A niche for isotopic ecology. Front Ecol Environ 5: $429-436$

Newsome SD, Clementz MA, Koch PL (2010) Using stable isotopes biogeochemistry to study marine mammal ecology. Mar Mamm Sci 26:509-572

Olavarría C, Aguayo-Lobo A, Bernal R (2001) Distribution of Risso's dolphin (Grampus griseus, Cuvier 1812) in Chilean waters. Rev Biol Mar Oceanogr 36:111-116

Pauly D, Trites AW, Capuli E, Christensen V (1998) Diet composition and trophic levels of marine mammals. J Mar Sci 55:467-481

Pierce GJ, Begoña Santos M, Learmonth JA, Mente E, Stowasser G (2004) Methods for dietary studies on marine mammals. In: Briand F (ed) Investigating the roles of cetaceans in marine ecosystems. CIESM Publisher, Venice, p 29-36

Pinedo MC, Rosas FCW (1989) Novas ocorrencias de Pseudorca crassidens (Cetacea, Delphinidae) para o atlántico sul ocidental, com observacoes sobre medidas cranianas e alimentacao. Atlantica 11:77-83

Porras Peters H, Aurioles Gamboa D, Cruz Escalona VH, Koch PL (2008) Trophic level and overlap of sea lions (Zalophus californianus) in the Gulf of California, Mexico. Mar Mamm Sci 24:554-576

Post DM (2002) Using stable isotopes to estimate trophic position: models, methods, and assumptions. Ecology 83: 703-718

Rau GH, Sweeney RE, Kaplan IR (1982) Plankton ${ }^{13} \mathrm{C}:{ }^{12} \mathrm{C}$ ratio changes with latitude: differences between northern and southern oceans. Deep-Sea Res A 29:1035-1039

Reeves RR, Smith BD, Crespo EA, Notarbatolo di Sciara G (2003) Dolphins, whales and porpoises: 2002-2010 conservation action plan for the world's cetaceans. IUCN/SSC Cetacean Specialist Group, IUCN, Gland, Switzerland and Cambridge, UK

Reyes JC, Van Waerebeek K (1995) Aspects of the biology of Burmeister's porpoise from Peru. Rep Int Whal Comm Spec Issue 16:349-364

Robineau D, Goodall RNP, Pichler F, Baker CS (2007) Description of a new subspecies of Commerson's dolphin, Cephalorhynchus commersonii (Lacépède, 1804), inhabiting the coastal Waters of the Kerquelen Islands. Mammalia 71: 172-180

Ross GJB (1979) The smaller cetaceans of the southeast coast of southern Africa. PhD dissertation, University of Port Elizabeth

Editorial responsibility: Michael Castellini,

Fairbanks, Alaska, USA
Schell DM, Saupe SM, Haubenstock N (1989) Natural isotope abundances in bowhead whale (Balaena mysticetus) baleen: markers of aging and habitat usage. In: Rundell PW, Ehlereinger JR, Nagy KA (eds) Stable isotopes in ecological research. Springer Verlag, New York, NY, p 261-269

Schell DM, Barnett DA, Vinette KA (1998) Carbon and nitrogen isotopes ratios in zooplankton of the Bearing, Chukchi and Beaufort seas. Mar Ecol Prog Ser 162:11-23

Schiavini ACM, Goodall RNP, Lescrauwaet AK, Koen Alonso M (1997) Food habits of the Peale's dolphin, Lagenorhynchus australis, review and new information. Rep Int Whal Comm 47:827-834

- Schoeninger MJ, DeNiro MJ (1984) Nitrogen and carbon isotopic composition of bone collagen from marine and terrestrial animals. Geochim Cosmochim Acta 48: 625-639

Sekiguchi K, Klages NTW, Best P (1992) Comparative analysis of the diets of smaller odontocete cetaceans along the coast of Southern Africa. In: Payne AIL, Brink KH, Mann $\mathrm{KH}$, Hilborn R (eds) Benguela trophic functioning. S Afr J Mar Sci 12:843-861

Sekiguchi K, Olavarría C, Morse L, Olson P and others (2006) The spectacled porpoise (Phocoena dioptrica) in Antarctic waters. J Cetacean Res Manag 8:265-271

Sheffield G, Grebmeier JM (2009) Pacific walrus (Odobenus rosmarus divergens): differential prey digestion and diet. Mar Mamm Sci 25:761-777

> Sheffield G, Fay FH, Feder H, Kelly BP (2001) Laboratory digestion of prey and interpretation of walrus stomach contents. Mar Mamm Sci 17:310-330

> Sheppard S, Harwood J (2005) Advances in molecular ecology: tracking trophic links through predator-prey foodwebs. Funct Ecol 19:751-762

Stacey PJ, Leatherwood S, Baird RW (1994) Pseudorca crassidens. Mamm Species 456:1-5

Staniland I (2002) Investigating the biases in the use of hard prey remains to identify diet composition using Antarctic fur seals (Arctocephalus gazelle) in captive feeding trials. Mar Mamm Sci 18:223-243

Torres DN, Aguayo AL (1979) Hábitos alimentarios de Lissodelphis peronii (Lacépède, 1804) en Chile central (Cetacea: Delphinidae). Rev Biol Mar Dep Oceanol Univ Chile 16:221-224

Van Waerebeek K, Oporto JA (1990) Observaciones preliminares sobre la biología de Lissodelphis peronii (Delphinidae) en el Pacífico Sureste. 4ta Reun Trab Esp Mam Acuát América del Sur, SOLIMAC, Valdivia, Chile, p 73

Vander Zanden MJ, Rasmussen JB (1996) A trophic position model of pelagic food webs: impact on contaminant bioaccumulation in lake trout. Ecol Monogr 66:451-477

> Viddi FA, Lescrauwaet AK (2005) Insights on habitat selection and behavioural patterns of Peale's dolphins (Lagenorhynchus australis) in the Strait of Magellan, Southern Chile. Aquat Mamm 31:176-183

Submitted: December 16, 2009; Accepted: September 14, 2010 Proofs received from author(s): November 5, 2010 